\title{
Poligami di Indonesia dalam Perspektif CEDAW dan Mazhab Shafi'i
}

\author{
Qurrotul Ainiyah \\ Sekolah Tinggi Ilmu Tarbiyah al-Umatul Wutsqo Jombang Jombang \\ E-mail:q_ainiy@yahoo.co.id \\ DOI: 10.18326/ijtihad.v16i1.61-84
}

Convention on the Elimination of All Forms of Discrimination against Women or CEDAW's paradigm of thought is gender equality, women should be given rights as men in principles and rights in marriage including marriage approval, marriage dismissal, marriage guardian, and so on. Discrimination is an attitude that opposite of justice and must be eliminated. The source of the CEDAW's concept paradigm of thought is mind, lustand feeling, and then the concept of CEDAW considered rational and Maslahah (good) enough. The Shafi'i paradigm is guiding the mind and heart based on religious texts. The religious prohibition have Madharat in the world and in the after life. If the world have not seen the Madharat, it will be feltin the after life. The Maslahah principle in CEDAW included al-Maslahab alMulghah, as it is contrary enough to the teachings of Islamic law contained in religious texts. In fact, any law that is contrary to Islamic law governed by religious texts is not Maslahah but Madharat and should be abandoned even it is logical and good enough by the reason of thought. CEDAW uses Nash's Guidelines that understand the Qur'an verse by considering Siyaq al-Kalam, so it interprets 'fair'by though of mindor in love and affection. Polygamy will no longer mu'asharah bi al-ma'ruf by causing the suffering of wives. With the Sad al-Dhariah consideration, it will change the polygamy law from allowed or mubăh to haram lighoiribi. Shafi'i madhhab uses the dalalah 'ibarah' which understands the Qur'an verse without considering siyaq al-kalam. The law of Haram li ghairibi on the permissibility of Polygamy based on Sad al-Dhariah is not applicable generally, and means that polygamy can not be judged as haram li ghairibi but keep see the conditions with the consideration of the single person condition.

Paradigma pemikiran CEDAW adalah persamaan gender, perempuan harus diberi hak sebagaimana laki-laki meliputi prinsip, persamaan hak dalam perkawinan, hak persetujuan perkawinan, hak pemutusan perkawinan, hak perwalian, dan seterusnya. Diskriminasi merupakan suatu sikap yang bertentangan dengan keadilan yang harus dihapuskan. Sumber konsep paradigma pemikiran CEDAW adalah akal pikiran, nafsu kemauan dan perasaan. sehingga konsep CEDAW dinilai cukup rasional dan Maslahah (kebaikan). Paradigma pemikiran Madzhab Syafi'i adalah akal pikiran dan hati yang didasarkan teks agama. Pelarangan agama pasti mengandung Madharat di dunia dan di akhirat. Jika di dunia belum 
ljtihad, Jurnal Wacana Hukum Islam dan Kemanusiaan, Volume 17, No. 1, Juni 2017: 61-84

tampak Madharatnya, pasti di akhirat akan dirasakan. Prinsip Maṣlahah dalam pemikiran CEDAW termasuk al-Maslahah al-Mulghah, karena cukup bertentangan dengan ajaran hukum Islam yang terdapat dalam teks agama. Segala hukum yang bertentangan dengan hukum Islam yang diatur teks agama, sebenarnya tidak Maslahah tetapi Madharat dan harus ditinggalkan walau cukup rasional dan Maslahah menurut akal pikiran. CEDAW menggunakan dalalăh al-nas yang memahami petunjuk ayat dengan mempertimbangkan Siyaq al-Kalam. Sehingga memaknai adil lebih bersifat pada rasa/kualitatif yaitu dalam cinta dan kasih sayang. Poligami akan semakin menjauhkan dari mu'asharah bi al-ma'ruf karena menyebabkan penderitaan istri. Dengan pertimbangan aad al-dhari'ah merubah hukum boleh/mubāh Poligami menjadi ḥarām li ghoiribi. Mazhab Syafi’i menggunakan dalālah 'ibārah yang memahami petunjuk ayat tanpa mempertimbangkan Siyaq al-kalam. Hukum Haram li ghairihi atas kebolehan Poligami dengan berdasarkan Sad al dhari'ah adalah tidak bisa diberlakukan secara umum. Ini berarti bahwa tidak bisa kemubahan Poligami ini ditarik secara tegas/umum menuju pada Haram li ghairihi, tetapi tetap melihat pada kondisi tertentu dengan pertimbangan kondisi si pelaku.

Keywords: Polygamy, CEDAW, Shafi'i mazhab

\section{Pendahuluan}

Salah satu bentuk perwujudan kepedulian PBB terhadap perlindungan hak asasi manusia adalah kepedulian terhadap segala bentuk diskriminasi. Hal ini ditunjukkan dengan adanya Deklarasi Universal tentang Hak Asasi Manusia (DUHAM) yang menyatakan semua orang berhak atas semua hak dan kebebasan tanpa pembedaan apapun seperti ras, warna kulit, jenis kelamin, bahasa, agama, politik atau pandangan lain, asal usul kebangsaan atau kemasyarakatan, hak milik, kelahiran ataupun kedudukan lain (Billah, 1994 : iiv).

Pada 18 Desember 1979 PBB mensahkan Konvensi tentang penghapusan segala bentuk diskriminasi terhadap perempuan yang dikenal dengan istilah CEDAW singkatan dari The Convention the Elimination of all Form af Discrimination againt Women. CEDAW menetapkan secara universal prinsip-prinsip menetapkan persamaan hak untuk perempuan, terlepas dari status perkawinan mereka, disemua bidang-politik, ekonomi, sosial, budaya dan sipil. Konvensi ini mendorong diberlakukannya perundang-undangan nasional yang melarang diskriminasi dan mengadopsi tindakan-tindakan khusus-sementara untuk mempercepat kesetaraan de facto antara laki-laki dan perempuan, termasuk merubah praktek kebiasaan dan budaya yang didasarkan pada inferioritas atau superioritas salah satu jenis kelamin atau peran stereotipe untuk perempuan dan laki-laki.

Pada tahun 1984, pemerintah Indonesia mensahkan UU no 7 tahun 1984 tentang ratifikasi CEDAW. Setelah sekian lama pemerintah Republik Indonesia meratifikasi CEDAW, masih 
belum terlihat banyak mencapai kemajuan. Indikasinya terlihat dari masih kuatnya diskriminasi terhadap perempuan, meningkatnya kasus kekerasan berbasis gender, tingginya angka kematian ibu melahirkan, maraknya kasus penjualan perempuan, tingginya angka poligami dan perkawinan anak-anak, bertambahnya jumlah perkawinan yang tidak dicatatkan, dan juga masih terdapatnya peraturan yang masih terlihat adanya diskriminasi terhadap perempuan (Mulia, 2006: 66).

Peradaban manusia terutama yang berkenaan dengan diskriminasi terhadap perempuan apakah dapat terjawab dengan memakai metode ijtihad yang dipakai oleh para imam madhhab ? Sebagai contoh masalah poligami, laki-laki boleh menikah dengan lebih dari satu perempuan, tetapi perempuan tidak diperbolehkan. Hal ini dianggap sebagai aturan yang rentan dengan perlakuan diskriminatif. Madhhab Syafi'i termasuk madhhab fikih yang cukup eksis, terus bertahan dan mendapatkan pengikut cukup banyak sampai sekarang.

\section{Poligami menurut CEDAW}

CEDAW adalah konvensi produk PBB ini menetapkan secara universal prinsip-prinsip menetapkan persamaan hak untuk perempuan, terlepas dari status perkawinan mereka, disemua bidang-politik, ekonomi, sosial, budaya dan sipil. Konvensi mendorong diberlakukannya perundang-undangan nasional yang melarang diskriminasi dan mengadopsi tindakan-tindakan khusus-sementara untuk mempercepat kesetaraan de facto antara lakilaki dan perempuan termasuk merubah praktek kebiasaan dan budaya yang didasarkan pada inferioritas atau superioritas salah satu jenis kelamin atau peran stereotipe untuk perempuan dan laki-laki.

Pada tahun 1992, PBB memformulasikan General Recommendation 19 yang secara khusus menggolongkan Gender Based Violance atau Violance that Affects Women Disproportionately and its Discriminatory sebagai kekerasan yang ditujukan kepada perempuan. Hak asasi perempuan adalah hak asasi manusia. Perempuan adalah manusia, sehingga apa yang diterapkan untuk manusia sepatutnya juga diterapkan pada kaum perempuan. Deklarasi tersebut menekankan bahwa kekerasan terhadap perempuan adalah bagian dari pelanggaran hak asasi manusia, dan merekomendasikan strategi yang harus dilaksanakan oleh negara anggota dan badan khusus PBB untuk menghilangkan kekerasan tersebut. Komite 
ljtihad, Jurnal Wacana Hukum Islam dan Kemanusiaan, Volume 17, No. 1, Juni 2017: 61-84

memberikan rekomendasi bagi negara peserta mengenai langkah-langkah yang perlu diambil untuk melaksanakan konvensi.

Konvensi ini menekankan pada kesetaraan (equality) dan keadilan (equity) laki-laki dan perempuan, yaitu persamaan hak dan kesempatan serta perlakuan di segala bidang dan kegiatan. Konvensi ini mengakui adanya : 1). Perbedaan biologis atau kodrati antara laki-laki dan perempuan; 2). Perbedaan perlakuan terhadap perempuan yang berbasis jender yang mengakibatkan kerugian pada perempuan; 3). Perbedaan kondisi dan posisi antara laki-laki dan perempuan, di mana perempuan menempati posisi yang lebih lemah karena mengalami diskriminasi.

Konvensi ini menekankan pada kesetaraan (equality) dan keadilan (equity) antara laki-laki dan perempuan, yaitu persamaan hak dan kesempatan serta perlakuan di segala bidang dan segala kegiatan sebagaimana yang tercantum dalam Konvensi-konvensi Hak Asasi Manusia, yaitu antara lain: hak atas kehidupan, hak atas persamaan, hak atas kemerdekaan dan keamanan pribadi, hak atas perlindungan yang sama di muka umum, hak untuk bebas dari segala bentuk diskriminasi, hak untuk mendapatkan pelayanan kesehatan fisik maupun mental yang sebaik-baiknya, hak atas pekerjaan yang layak dan kondisi yang baik, hak untuk tidak mengalami penganiayaan atau kekejaman lain secara tidak manusiawi dan sewenang wenang.

Ketentuan subtantif CEDAW mengacu pada kesetaraan, persamaan substantif, non diskriminasi dan akuntabilitas serta tanggung jawab negara yang berkenaan dengan status dan hak perempuan dari berbagai bidang. Khusus mengenai hukum keluarga ada pada pasal 16 yaitu bidang khusus perkawinan, keluarga, hak atas anak dan harta benda perkawinan karena dirasa masih ada beberapa hal yang mengalami perbedaan persepsi antara isi pasal 16 CEDAW dengan pemahaman hukum agama (Islam). Paradigma yang digunakan CEDAW secara umum adalah persamaan gender di mana perempuan harus diberi hak sebagaimana yang telah dimiliki oleh laki-laki meliputi prinsip-prinsipnya, persamaan hak dalam perkawinan dan unsur-unsur terkait, persamaan hak persetujuan perkawinan, persamaan hak pemutusan perkawinan, hak dan tanggung jawab yang sama dalam mengurusi anak, persamaan hak perwalian, dan seterusnya. Prinsip-prinsip ini juga tampak cukup rasional, mengingat wanita juga manusia sebagaimana laki-laki, yang sudah sepantasnya disejajarkan. Jika laki-laki boleh melakukan sesuatu maka wanita juga boleh. Jika yang diperbolehkan 
hanya laki-laki sementara wanita tidak, rasionalnya itu dinamakan diskriminasi. Diskriminasi merupakan suatu sikap yang bertentangan dengan keadilan yang harus dihapuskan.

\section{Poligami dalam perundang-undangan di Indonesia}

Definisi Perkawinan dalam Pasal 1 Undang-undang Nomor 1 tahun 1974 tentang perkawinan adalah "Ikatan lahir dan batin antara seorang pria dan wanita sebagai suami istri dengan tujuan membentuk keluarga (rumah tangga) yang bahagia dan kekal berdasarkan Ketuhanan Yang Maha Esa". Sedangkan dalam Pasal 2 Kompilasi Hukum Islam disebutkan "Perkawinan menurut Islam adalah pernikahan, yaitu akad yang sangat kuat atau Mithaqan Galidzah untuk mentaati perintah Allah dan melaksanakannya merupakan ibadah”. Sedangkan dalam Counter Legal Draft Kompilasi Hukum Islam (CLD-KHI) memberikan definisi "Perkawinan adalah akad yang sangat kuat (Mitsaqan Gholidzah) yang dilakukan secara sadar oleh seorang laki-laki dan seorang perempuan untuk membentuk keluarga yang pelaksanaannya didasarkan pada kerelaan dan kesepakatan kedua belah pihak" (Mulia, 2006: 151).

Permasalahan beristri lebih dari satu (Poligami) sering memunculkan pro dan kontra. Dalam pasal 3 Undang-Undang Perkawinan No 1 tahun 1974 :

(1) Pada asasnya seorang pria hanya boleh memiliki seorang isteri. Seorang wanita hanya boleh memiliki seorang suami.

(2) Pengadilan dapat memberi izin kepada seorang suami untuk beristeri lebih dari seorang apabila dikendaki oleh pihak-pihak yang bersangkutan.

Lebih lanjut pasal 4 berbunyi:

(1) Dalam hal seorang suami akan beristri lebih dari seorang, sebagaimana tersebut dalam pasal 3 ayat (2) Undang-undang ini, maka ia wajib mengajukan permohonan ke Pengadilan di daerah tempat tinggalnya.

(2) Pengadilan dimaksud dalam ayat (1) pasal ini hanya memberi izin kepada suami yang akan beristri lebih dari seorang apabila:

a. istri tidak dapat menjalankan kewajibannya sebagai isteri;

b. istri mendapat cacat badan atau penyakit yang tidak dapat disembuhkan;

c. istri tidak dapat melahirkan keturunan. 
ljtihad, Jurnal Wacana Hukum Islam dan Kemanusiaan, Volume 17, No. 1, Juni 2017: 61-84

Dalam Pasal 5 UU Perkawinan tersebut lebih lanjut menentukan:

(1) Untuk dapat mengajukan permohonan ke pengadilan sebagaimana dimaksud dalam pasal 4 Undang-Undang ini harus memenuhi syarat-syarat berikut:

a. Adanya persetujuan dari isteri/isteri-isteri;

b. Adanya kepastian bahwa suami mampu menjamin keperluan-keperluan hidup isteriisteri dan anak-anak mereka;

c. Adanya jaminan bahwa suami akan berlaku adil terhadap isteri-isteri dan anak-anak mereka.

(2) Persetujuan yang dimaksud dalam ayat (1) huruf a pasal ini tidak diperlukan bagi seorang suami apabila isteri/isteri-isterinya tidak mungkin dimintai persetujuannya dan tidak dapat menjadi pihak dalam perjanjian; atau apabila tidak ada kabar dari istrinya selama sekurangkurangnya 2 (dua) tahun atau karena sebab-sebab lainnya yang perlu mendapat penilaian dari Hakim Pengadilan.

Persyaratan yang membolehkan seorang suami poligami sebagaimana ditentukan dalam pasal 4 adalah hanya berdasar pada kondisi yang ada pada istri yang menjadikan kebolehan bagi suami untuk menikah lagi. Bagaimana jika yang sakit adalah suami, atau yang diprediksi tidak mempunyai keturunan mandul atau sperma tidak sehat/tidak mampu membuahi adalah sang suami atau yang tidak bisa menjalankan kewajibannya adalah suami (Impoten)? Maka tentu solusinya tidak mungkin poliandri atau mungkin si istri akan mengajukan gugatan cerai (Khulu')? padahal istri yang meminta/ menggugat cerai, maka diancam tidak akan mencium bau Surga. Jangankan masuk Surga, mencium baunya Surga saja tidak bisa.

Persyaratan lain yang ada pada suami adalah pertimbangan kemampuan adil terhadap para istri dan anak-anaknya. Keadilan batiniyah biasanya diukur dengan keadilan dalam menggilir atau membagi hari-hari kebersamaannya. Jika rasa adil itu dilihat dari sisi suami, maka ketika suaminya sudah memberikan nafkah kepada para istri dan anak-anaknya, maka dia menganggap sudah mampu berbuat adil. Tapi bagaimana dengan pandangan rasa keadilan dari sisi istri dan anak-anaknya.

Sedangkan dalam Kompilasi Hukum Islam (KHI) pasal 55 mengaturnya:

(1) Beristri lebih dari satu orang pada waktu bersamaan, terbatas hanya sampai 4 istri; 
(2) Syarat utama beristri lebih dari seorang, suami harus mampu berlaku adil terhadap istri-istri dan anak-anaknya;

(3) Apapila syarat utama yang disebut dalam ayat (2) tidak mungkin dipenuhi, suami dilarang beristri lebih dari satu.

Tidak berbeda dengan UUP, Kompilasi Hukum Islam (KHI) juga memperbolehkan poligami, dengan persyaratan kemampuan berbuat adil. KHI menjelaskan pengertian dan batasan adil. Adil diwujudkan dalam bentuk surat pernyataan akan berbuat adil dan surat keterangan penghasilan (materi) yang akan dipakai pertimbangan majlis hakim untuk bisa mengukur kemampuan seorang suami memberi nafkah lahir dengan layak kepada para istri-istrinya. Persyaratan lain yang dibutuhkan adalah persetujuan istri. Timbul pertanyaan adakah seorang istri yang bersedia dan memberikan persetujuan suami menikah lagi ?. KHI mengatur kebolehan Poligami dengan alasan adanya kekurangan pihak isteri, terutama dalam hal pemuas nafsu seks suami, istri yang sakit akut/cacat tetap atau karena tidak mempunyai keturunan. Secara garis besar bahwa poligami itu adalah sebuah solusi alternatif yang bisa ditempuh suami karena ada kekurangan dari pihak isteri. Apa solusi alternatifnya jika kekurangan itu ada pada sang suami?

Selain UUP dan KHI maka dikenal Legal Draft Kompilasi Hukum Islam yang dikenal dengan singkatan CLD-KHI yang diakuinya sebagai produk yang lebih Pluralis dan Demokratis. Faktor-faktor yang mendorong lahirnya CLD-KHI adalah pertama, rumusan hukum Islam model baru yang disusun berdasarkan prinsip-prinsip dasar ajaran Islam sebagaimana terbaca dalam al-Qur'an dan Sunnah Nabi yang sangat menghormati hak asasi manusia, mengadvokasi kesetaraan dan keadilan gender dalam relasi laki-laki dan perempuan, menyuarakan pandangan yang humanis, pluralis dan demokratis.

Kedua, ajaran Islam terdiri dr ajaran dasar dan non dasar. Yang dasar diyakini berasal dari Allah yang bersifat mutlak, kekal, absolut dan yang tidak bisa diubah, yaitu al-Qur'an dan Hadis. Yang termasuk non dasar adalah Fiqh yang paling banyak dipakai masyarakat muslim. Sebagai hasil rekayasa olah pikir manusia yang cerdas, yang berasal dari penggalian al-Qur'an dan Hadis, maka sangat dimungkinkan dalam fiqh terdapat kesalahan, kekurangan ataupun tidak lagi sesuai dengan masanya, karena dipengaruhi oleh faktor sosio kultural dan 
ljtihad, Jurnal Wacana Hukum Islam dan Kemanusiaan, Volume 17, No. 1, Juni 2017: 61-84

sosio historis masyarakat pada masa hidup sang mujtahid, sehingga tidak mungkin hasil ijtihad itu berlaku abadi sepanjang masa, tetapi dalam kurun waktu tertentu masih memungkinkan untuk berubah.

Ketiga, ajaran Islam mempunyai 2 (dua) aspek penting yaitu vertikal (ḅablun min Allah) yang mengatur kewajiban manusia pada Allah, dan horizontal (hablun Min al-Näs) yang mengatur hubungan sesama manusia. Aspek vertikal lebih dipentingkan, sehingga kadang aspek humanis yang merupakan refleksi dari aspek vertikal kurang mendapat perhatian.

Keempat, memahami hakikat perkawinan dalam Islam harus dilakukan dengan memahami seluruh ayat al-Qur'an yang berkenaan dengan masalah perkawinan dengan menggunakan metode tematik dan holistik, kemudian diambil benang merah dari keseluruhan penjelasan ayat-ayat tersebut. Dari kajian tersebut, dihasilkan 5 (lima) prinsip dasar perkawinan Islam, yaitu monogami, mawaddah wa rahmah, Saling melengkapi dan melindungi, mu'asharah bil ma'rüf baik dalam relasi seksual, kemanusiaan dan kebebasan memilih jodoh baik bagi laki-laki maupun perempuan.

Kelima, adanya usulan dari Direktorat Peradilan Agama pada tahun 2003 mengusulkan status hukum KHI dari Inpres menjadi UU, juga mengusulkan perkawinan yang tidak dicatatkan adalah pelanggaran hukum yang harus ada sanksi hukumnya. Hal ini dikarenakan berdasar penelitian ada sekitar 48\% perkawinan yang tidak dicatatkan (unregistered) yang hal itu dapat merugikan hak-hak istri dan keturunannya.

Keenam, adanya upaya formalisasi syari'at Islam dari beberapa daerah di wilayah Indonesia yang terkesan belum memiliki konsep yang jelas mengenai konsep syari'at yang akan dipergunakan. Untuk menjawab hal tersebut dengan menawarkan KHI baru yang lebih memperhatikan nilai Islam yang esensial, seperti keadilan, kemaslahatan, kesetaraan dan lebih akomodatif terhadap nilai-nilai dan kearifan budaya lokal.

Maka kemudian dengan bermodalkan naskah KHI, tim CLD-KHI mengubah kerangka berfikir dalam pembentukan Hukum Islam, yaitu dari teosentris ke antroposentris, dari elitis ke populis, dari deduktif ke induktif dan dari eisegese ke exeges (penjelasan/penafsiran).

Ada 6 (enam) prinsip dasar pembentukan CLD-KHI, yaitu: pluralisme (ta'addudiyah), nasionalitas (muwațanah), penegakan HAM (Iqāmat al-ḅuqūq al Insāniyyah), demokrasi (dimuqrat\} iyyah, kemaslahatan (maslahat) dan kesetaraan Gender (al-musawah al-jinsiyab). Keenam 
prinsip dasar inilah yang kemudian menjiwai seluruh ketentuan fiqh yang dihasilkan oleh CLD-KHI. Ada 23 poin tawaran pembaharuan hukum keluarga Islam versi CLD-KHI, di antaranya adalah: 1). Perkawinan bukan ibadah, tetapi akad sosial kemanusiaan (mu'amalah). 2). Pencatatan perkawinan oleh pemerintah adalah rukun perkawinan. 3). Perempuan bisa menikahkan sendiri dan menjadi wali nikah. 4). Mahar bisa diberikan oleh calon suami dan calon isteri. 5). Poligami dilarang (ḥaräm li ghairihi). 6). Perkawinan dengan pembatasan waktu diperbolehkan. 7). Perkawinan antar agama diperbolehkan. 8). Istri memiliki hak talak dan hak rujuk. 10). Hak dan kewajiban suami dan isteri setara.

Masalah poligami di Indonesia, dijelaskan dalam Pasal 3 CLD-KHI, yaitu: 1). Asas perkawinan adalah Monogami (Tawahbud al-zawj). 2). Perkawinan yang dilakukan di luar asas sebagaimana pada ayat (1) dinyatakan batal secara hukum (Mulia, 2006 : 165). Hal ini berarti Poligami di Indonesia sama sekali tidak diperbolehkan dengan keadaan atau alasan apa pun, jika terjadi maka secara otomatis perkawinan tersebut batal demi hukum (tidak sah). Dasar pertimbangannya adalah Q.S. al-Nisa' (4) ayat 3 yang dilihat dari sebab turunnya bukan aturan poligami, tetapi berhubungan dengan perlindungan terhadap anak yatim dengan peringatan agar manusia menghindari segala macam bentuk perilaku tidak adil dan semenamena, terutama dalam hal pernikahan seorang pemelihara anak yatim dengan anak yatim yang diasuhnya. Karena itu, untuk merumuskan hukum diperlukan tafsir tematik/Maudhu’i.

Lebih jauh dijelaskan, menghukumi poligami tidak hanya diambil dari satu ayat saja, melainkan harus berdasar pada ayat-ayat yang lain, yaitu surat al-Nisa' (4) ayat 129 yang menjelaskan tentang ketidakmampuan manusia bisa berbuat adil, karena pasti akan ada kecenderungan kepada salah satunya. Begitu pula surat al-Nisa' (4) ayat 19 yang menyatakan hendaknya para suami bersabar terhadap kemungkinan adanya sifat istri yang mungkin tidak disukainya, karena dibalik itu masih ada kebaikan yang lain. Oleh karena itu, demi penegakan keadilan, Allah memperingatkan 2 (dua) hal kepada para suami. Pertama, jangan menikahi anak yatim perempuan yang berada di bawah perwaliannya, kalau tidak mampu berbuat adil. Kedua, jangan Poligami kalau tidak mampu berbuat adil karena dengan merujuk surat al-Nisa' ayat 129. Hal ini pentingnya menggunakan Tafsir Tematik dalam memahami suatu persoalan dalam al-Qur'an (Mulia, 2006 : 116-117). 
ljtihad, Jurnal Wacana Hukum Islam dan Kemanusiaan, Volume 17, No. 1, Juni 2017: 61-84

Pendapat ini juga dikuatkan dengan dalih penggunaan dalalah al-nas $\}$ yang memahami petunjuk ayat dengan mempertimbangkan Siyāq al-Kalam, sehingga kaum feminis muslim memaknai adil lebih bersifat pada rasa/kualitatif yaitu dalam cinta dan kasih sayang. Kaum feminis muslim juga menguatkan pendapatnya dengan beberapa penelitian tentang dampak poligami yang menimbulkan rasa bermusuhan bagi para istri (Women Womini Lupus). Sedangkan bagi suami tidak bisa memperhatikan istri dan anak-anaknya secara optimal, karena waktu kebersamaan yang terbatas. Ini semakin membuktikan bahwa poligami akan semakin menjauhkan dari mu'äsharah bi al-ma'rüf karena menyebabkan penderitaan istri. Dengan pertimbangan Sad al- dhariah, para pakar feminis merubah hukum boleh/mubah Poligami menjadi ḥaram li ghairihi. Sadd al dharì ah adalah upaya mujtahid untuk menetapkan larangan terhadap satu kasus hukum yang pada dasarnya berhukum mubah (Hamidah, 2011 : 126). Larangan tersebut dimaksudkan untuk menghindari perbuatan atau tindakan lain yang dilarang. Dengan kata lain tindakan ini adalah sebagai langkah preventif segala sesuatu yang diperbolehkan tetapi membawa dampak yang buruk yang bisa mengarah pada keharaman, maka dihukumi haram.

Dhariah menurut Ibn Qayyim, berarti sesuatu yang menjadi perantara dan jalan kepada sesuatu lainnya. Sedangkan sadd secara bahasa berarti menutup. Jika kata sadd digabungkan dengan kata dhari'ah maksudnya adalah menutup jalan terjadinya kerusakan. Setiap perbuatan yang secara sadar dilakukan pasti memiliki maksud dan tujuan tertentu. Sebelum sampai pada pelaksanaan perbuatan yang dituju tersebut ada serentetan perbuatan yang mendahului, yang harus dilalui. Serentetan perbuatan yang mendahului tersebut dinamakan dhari'ah, sementara menutup jalannya disebut sadd. Maka Sadd al dhariah adalah menutup jalan yang membawa kebinasaan atau kejahatan, atau menutup jalan yang membawa pada perbuatan yang dilarang dan mengandung kemudharatan. Menurut al-Satibi melaksanakan suatu pekerjaan yang semula mengandung kemaslahatan. Hal ini berarti bahwa diduga perbuatan tersebut sebelumnya mengandung kemaslahatan tetapi berakhir dengan suatu kerusakan. Menutup jalan tersebut dengan mengharamkan perbuatan tersebut. Oleh sebab itu akan

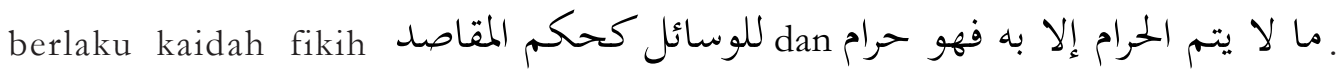
Keharaman di sini bukanlah haram li dhatihi tetapi haram li ghairihi. Lebih lanjut dijelaskan, bahwa suatu perbuatan itu menjadi dilarang (haram) dengan kriteria: 1). Perbuatan yang 
tadinya diperbolehkan (mubah) itu mengandung kerusakan. 2). Kemafsadatannya lebih kuat dibandingkan dengan kemaslahatannya. 3). Perbuatan yang diperbolehkan shara'mengandung lebih banyak unsur kemanfatannya.

Poligami yang dipandang sebagai alternatif solusi dari pada perzinaan, itu pun dipandang secara sepihak yaitu kepentingan suami saja. Contoh seorang suami berkeinginan melakukan hubungan suami istri yang tidak mungkin ditunda barang sehari, sedangkan sang istri dalam keadaan Haid yang waktunya kurang lebih 1 minggu. Maka punya istri lebih dari satu dianggap sebagai alternatif jitu untuk mencegah terjadinya perzinaan sang suami karena tidak bisa menahan nafsunya. Padahal dalam sebuah hadis dinyatakan Allah menciptakan nafsu seksual dalam sepuluh bagian. Sembilan bagian untuk perempuan dan satu bagian untuk laki-laki. Allah juga menciptakan kekuatan akal dalam sepuluh bagian. Sembilan bagian untuk laki-laki dan satu bagian untuk perempuan. Hal ini berarti perempuan mempunyai sembilan nafsu dan satu akal, sedangkan laki-laki mempunyai sembilan akal dan satu nafsu. Oleh karena itu, sebaik-baiknya perempuan adalah yang bisa menggunakan satu bagian akalnya untuk mampu menundukkan sembilan nafsunya. Dan jika laki-laki berpoligami karena tidak mampu menahan nafsunya dan mencegah terjadinya perzinaan, maka berarti sembilan bagian akalnya tidak mampu mengendalikan satu nafsunya.

Kebolehan poligami dipandang sebagai langkah solusi daripada terjadinya perceraian, yang walaupun diperbolehkan tetapi sangat dibenci oleh Allah. Daripada bercerai, yang akan berakibat buruk pada istri dan anak-anaknya, maka berpoligami adalah solusi alternatifnya. Argumen ini dipandang terlalu mengada-ada, karena akibat dari poligami bagi para istri dan anak-anaknya tidak kalah hebatnya dibandingkan dengan akibat adanya perceraian. Secara psikologis akan timbul saling cemburu antara para istri dan akan muncul permasalahan antar anak dari ibu-ibu yang berlainan.

Argumentasi yang menyatakan Poligami sebagai langkah preventif dari adanya prostitusi. Argumen ini juga sangat berpihak pada laki-laki, yaitu hanya memandang pemenuhan kebutuhan libido sang suami. Artinya ketika sang suami menginginkan terpenuhi nafsunya, maka sudah ada yang selalu siap melayaninya. Jika dia hanya punya satu istri, kemudian sang istri sedang haid, atau nifas, maka sang suami masih bisa mendatangi istrinya yang lain. Lalu bermuncullah beberapa pertanyaan: 1). Bagaimana jika seorang suami mempunyai empat 
ljtihad, Jurnal Wacana Hukum Islam dan Kemanusiaan, Volume 17, No. 1, Juni 2017: 61-84

istri yang haid dalam waktu yang bersamaan? Laki-laki hanya mempunyai satu bagian nafsu dan sembilan bagian akal? seharusnya satu nafsu itu bisa dikendalikan oleh sembilan bagian akalnya. 2). Bagaimana jika seorang istri menginginkan penyaluran nafsu sedang suami sedang tidak di rumah atau di tempat istrinya yang lain? Sang istri akan sabar menanti sampai hari gilirnya. Berarti satu bagian akal bisa mengendalikan desakan sembilan nafsu.

Kontroversi tentang Poligami ini karena adanya pihak yang setuju dengan Poligami dan ada pihak yang tidak setuju. Kontoversi itu dapat digambarkan sebagai berikut :

Tabel 1

Kontroversi tentang poligami

\begin{tabular}{|c|c|c|c|}
\hline No & Argumentasi & Setuju & Tidak setuju \\
\hline 1. & Keadilan & $\begin{array}{l}\text { Jika suami yakin bisa } \\
\text { adil }\end{array}$ & $\begin{array}{l}\text { Suami tidak mungkin bisa adil, } \\
\text { jika bisa hanya adil materi }\end{array}$ \\
\hline 2. & Alternatif solusi & $\begin{array}{l}\text { Lebih baik Poligami } \\
\text { dari pada perzinaan }\end{array}$ & $\begin{array}{l}\text { Jika ada yang harmonis dengan } \\
\text { poligami, tapi lebih banyak yang } \\
\text { menderita }\end{array}$ \\
\hline 3. & $\begin{array}{l}\text { Solusi lain dari } \\
\text { perceraian }\end{array}$ & $\begin{array}{l}\text { Perceraian sangat } \\
\text { dibenci Allah }\end{array}$ & $\begin{array}{l}\text { Dampak poligami tidak lebih baik } \\
\text { daripada dampak perceraian }\end{array}$ \\
\hline 4. & $\begin{array}{l}\text { Pencegahan } \\
\text { terhadap Prostitusi }\end{array}$ & Dari pada suami "jajan" & $\begin{array}{l}\text { Poligami bukan solusi } \\
\text { mencegah/menghin dari } \\
\text { prostitusi }\end{array}$ \\
\hline 5. & $\begin{array}{l}\text { Jumlah perempuan } \\
\text { lebih banyak dari } \\
\text { pada laki-laki }\end{array}$ & $\begin{array}{l}\text { Berbagi antar } \\
\text { perempuan }\end{array}$ & $\begin{array}{l}\text { Jumlah laki-laki dan perempuan di } \\
\text { Indonesia hampir seimbang. } \\
\text { Apa bisa laki-laki dibagi? }\end{array}$ \\
\hline
\end{tabular}

Walaupun CLD-KHI tidak diterima atau ditolak menjadi Undang-undang, tetapi ini menjadi bukti adanya pemikiran baru yang sudah mempengaruhi pada perkembangan pembentukan hukum keluarga di Indonesia dan telah nampak konsep dalam CEDAW telah mempengaruhi perumusan hukum yang ada di CLD-KHI tersebut.

Beberapa permasalahan yang ada dalam undang-undang perkawinan, yang kemudian mengalami perubahan karena adanya perubahan dasar pemikirannya sebagaimana tabel di bawah ini : 
Tabel 2

Perubahan Konsep dalam Hukum Perkawinan

\begin{tabular}{|c|c|c|c|c|}
\hline No & Materi & UU No.1/1974 & KHI & CLD-KHI \\
\hline 1. & Perkawinan & $\begin{array}{l}\text { Berdasarkan } \\
\text { Ketuhanan Yang } \\
\text { Maha Esa (Ps. 1)) }\end{array}$ & $\begin{array}{l}\text { Pelaksanaannya } \\
\text { ibadah (Ps. 2) }\end{array}$ & $\begin{array}{l}\text { Perkawinan adalah } \\
\text { mu'amalah/kontrak } \\
\text { kesepakatan (Ps. 2) }\end{array}$ \\
\hline 2. & $\begin{array}{l}\text { Rukun } \\
\text { perkawinan }\end{array}$ & $\begin{array}{l}\text { Calon mempelai, } \\
\text { wali, saksi, dadn } \\
\text { akad }\end{array}$ & $\begin{array}{l}\text { Calon mempelai, } \\
\text { wali, dan saksi }\end{array}$ & $\begin{array}{l}\text { Ditambah pencatatan } \\
\text { perkawinan }\end{array}$ \\
\hline 3. & $\begin{array}{l}\text { Kedudukan } \\
\text { wali nikah }\end{array}$ & $\begin{array}{l}\text { Wali merupakan } \\
\text { rukun perkawinan }\end{array}$ & $\begin{array}{l}\text { Wali merupa kan } \\
\text { rukun } \\
\text { perkawinan }\end{array}$ & $\begin{array}{l}\text { Perempuan tidak harus } \\
\text { ada wali nikahnya }\end{array}$ \\
\hline 4. & $\begin{array}{l}\text { Pencatatan } \\
\text { perkawinan }\end{array}$ & $\begin{array}{l}\text { Keharusan untuk } \\
\text { administrasi (Ps. 2) }\end{array}$ & $\begin{array}{l}\text { Bukan rukun } \\
\text { perkawinan (Ps. } \\
14)\end{array}$ & $\begin{array}{l}\text { Merupakan rukun } \\
\text { Perkawinan (Ps. 6) }\end{array}$ \\
\hline 5. & $\begin{array}{l}\text { Saksi } \\
\text { perempuan } \\
\text { dalam } \\
\text { perkawinan }\end{array}$ & $\begin{array}{l}\text { Saksi perkawinan } 2 \\
\text { orang lelaki (Ps. 26) }\end{array}$ & $\begin{array}{l}\text { Perempuan tidak } \\
\text { boleh menjadi } \\
\text { saksi (Ps. 25) }\end{array}$ & $\begin{array}{l}\text { Perempuan boleh jadi } \\
\text { saksi (Ps.11) }\end{array}$ \\
\hline 6. & $\begin{array}{l}\text { Batas usia } \\
\text { perkawinan }\end{array}$ & $\begin{array}{l}16 \text { tahun (wanita) } \\
19 \text { tahun (laki-laki) } \\
\text { (Ps. } 7 \text { ) }\end{array}$ & $\begin{array}{l}16 \text { tahun } \\
\text { (wanita), } 19 \\
\text { tahun (laki-laki) } \\
\text { (Ps. 15) }\end{array}$ & $\begin{array}{l}\text { Minimal } 19 \text { tahun baik } \\
\text { wanita dan lelaki (Ps.7) }\end{array}$ \\
\hline 7. & $\begin{array}{l}\text { Wali nikah } \\
\text { bagi gadis }\end{array}$ & $\begin{array}{l}\text { Harus ada wali } \\
\text { nikah }\end{array}$ & $\begin{array}{l}\text { Harus ada wali } \\
\text { (Ps.14) }\end{array}$ & $\begin{array}{l}\text { Gadis usia } 21 \text { tahun } \\
\text { lebih bisa nikah tanpa } \\
\text { wali (Ps. 7) }\end{array}$ \\
\hline 8. & Mahar & $\begin{array}{l}\text { Calon suami wajib } \\
\text { memberi mahar } \\
\text { pada istri }\end{array}$ & $\begin{array}{l}\text { Calon suami } \\
\text { wajib memberi } \\
\text { mahar pada istri } \\
\text { (Ps.30) }\end{array}$ & $\begin{array}{l}\text { Mahar bisa dari calon } \\
\text { istri pada calon suami } \\
\text { atau sebaliknya (Ps. 16) }\end{array}$ \\
\hline 9. & $\begin{array}{l}\text { Kedudukan } \\
\text { suami istri }\end{array}$ & $\begin{array}{l}\text { Suami sebagai } \\
\text { kepala keluarga dan } \\
\text { istri adalah Ibu } \\
\text { rumah tangga (Ps. } \\
\text { 31) }\end{array}$ & $\begin{array}{l}\text { Suami sebagai } \\
\text { kepala keluarga } \\
\text { dan istri adalah } \\
\text { Ibu rumah } \\
\text { tangga (Ps. } 79 \text { ) }\end{array}$ & $\begin{array}{l}\text { Kedudukan, hak dan } \\
\text { kewajiban suami istri } \\
\text { adalah setara (Ps. 49) }\end{array}$ \\
\hline 10. & Poligami & $\begin{array}{l}\text { Boleh dengan } \\
\text { sejumlah } \\
\text { persyaratan (Ps. 3-5) }\end{array}$ & $\begin{array}{l}\text { Boleh dengan } \\
\text { sejumlah syarat } \\
\text { (Ps. 55-59) }\end{array}$ & $\begin{array}{l}\text { Tidak boleh, haram } \\
\text { Lighairibi (Ps.3) }\end{array}$ \\
\hline 11. & Iddah & Hanya istri (Ps.11) & $\begin{array}{l}\text { Hanya istri (Ps. } \\
153 \text { ) }\end{array}$ & $\begin{array}{l}\text { Berlaku bagi suami dan } \\
\text { istri (Ps. } 88 \text { ) }\end{array}$ \\
\hline
\end{tabular}


ljtihad, Jurnal Wacana Hukum Islam dan Kemanusiaan, Volume 17, No. 1, Juni 2017: 61-84

\section{Poligami menurut mazhab Shafi'i}

Syari'at Allah diyakini mengandung kebaikan (mașlạ̣ah) dan keadilan. Barometer mașlaḥah dan keadilan bukan dalam perspektif akal manusia yang sangat terbatas, tetapi menurut Allah SWT. Mașlạ̣ah mencakup dua sisi, mașlaḥah di dunia dan maṣlạ̣ah di akhirat. Hukum Islam bukan hanya berdampak pada mașlạ̣ah di dunia saja, lebih dari itu hukum Islam paling menentukan untuk kebaikan manusia ketika hidup di akhirat. Terkait mașlạ̣ah di dunia, terkadang dapat ditangkap oleh manusia dan terkadang juga tidak bisa ditangkap. Kemaslahatan di dunia tidak bisa ditangkap dan keadilan tidak dapat direalisasikan, tetapi seorang muslim tetap wajib taat dan patuh pada tata aturan hukum Allah. Ketika manusia tidak mentaati hukum Allah, maka dimasukkan dalam kategori kafir, zalim dan fasiq (Q.S. al-Maidah: 44, 45, 47).

Dalam ilmu ushul fikih, dikenal 3 (tiga) macam kategori maṣlạ̣ah, yaitu mu'tabarah, mulgāh dan mursalah. Mașlaḥah yang dapat dijadikan sebagai landasan hukum adalah al-Maslahah alMu'tabarah, sedangkan yang didasarkan pada akal pikiran, nafsu dan perasaan dikategorikan sebagai al-mașlaḥah al-Mulgāh yang tidak dapat dijadikan sebagai landasan hukum, sebab bertentangan dengan teks agama, sekalipun menurut akal ada kebaikannya. sedangkan maslạ̣ah al-Mursalah adalah kemaslahatan yang disandarkan pada kemaslahatan menurut akal pikiran sekalipun tidak bertentangan dengan nash agama. Begitu juga dengan konsep madarat yang mempunyai dua sisi, yaitu di dunia dan di akhirat. Madarat di dunia bentuknya dapat menimbulkan kerusakan dan bahaya, sementara madarat di akhirat adalah masuk neraka. Semua hukum yang bersifat larangan pasti mendatangkan madarat baik di dunia maupun di akhirat. Andai kemaḍaratan tidak tampak di dunia, pasti di akhirat akan mengetahui akibatnya.

Mazhab Shafi'i lebih menekankan pada pemahaman teks yaitu al-Qur'an dan Hadis, baru kemudian pada penggunaan akal. Jika sudah diatur dan dijelaskan dalam nash, maka penggunaan sumber lain (akal) tidak diperbolehkan lagi. Meskipun dalam pemikiran hukumnya beliau dikategorikan tokoh moderat, memadukan wahyu dan akal, tetapi beliau lebih mengutamakan wahyu dengan tujuan untuk penegakan otoritas nash agar mencakup seluruh kehidupan masyarakat secara umum. Sehingga beliau dikenal dengan julukan Nậir al-Sunnah. Mazhab Shafi'i dalam kitab al-Umm menjelaskan bahwa seluruh masalah pasti diketemukan jawabannya di dalam al-Quran, termasuk melalui Qiyas, sehingga al-mașlaḥah 
al-Mursalah tidak diperlukan lagi. Oleh sebab itu, Mazhab Syafi'i dikenal sebagai mazhab fikih yang paling sering menggunakan metode Qiyas yang tidak mau menggunakan almașlaḥah al-Mursalah, apalagi dengan al-mașlahah al-Mulgah.

Tidak ada satupun para sahabat dan imam-imam mazhab fikih, termasuk imam Syafi'i, yang menyangkal kebolehan Poligami, sekalipun mereka menetapkan varian hukum kondisionalnya. Hal ini dengan berdasar pada al-Quran surat al-Nisa' (4): 3:

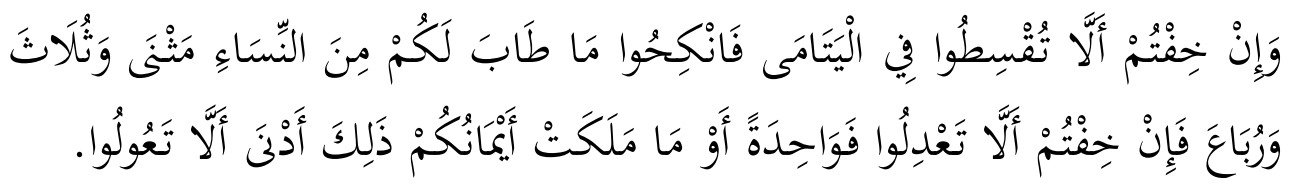

Dilihat dari sebab turunnya ayat, beberapa pendapat mengatakan bahwa ayat tersebut tentang perlakuan terhadap anak yatim yang di bawah pengasuhan seorang wali. Turunnya ayat di atas dilatarbelakangi adanya adanya pertanyaan dari Urwah bin Zubair kepada Aisyah RA, istri nabi Muhammad SAW tentang mengawini anak yatim yang dibawah asuhannya. Maka kemudian Nabi menjawab : "Wahai anak saudara perempuanku, yatim disini maksudnya adalah anak perempuan yatim yang berada di bawah asuhan walinya, yang mempunyai harta kekayaan bercampur dengan harta kekayaannya, serta kecantikannya membuat pengasuh anak yatim itu senang padanya, lalu ingin menjadikannya sebagai istri, tetapi tidak mau memberi mahar dengan adil yaitu memberi mahar yang sebagaimana lazimnya diberikan kepada perempuan lain. Karena itu, pengasuh anak yatim yang seperti itu dilarang menikahi mereka, kecuali kalau mereka mau berbuat adil dengan memberikan mahar yang lebih tinggi dari pada biasanya. Jika mereka tidak dapat berbuat demikian, maka mereka diperintahkan untuk menikahi perempuan-perempuan lain yang disenanginya.

Imam Shafi'i menyatakan bahwa kebolehan menikah sampai empat hanya ditujukan kepada laki-laki merdeka, dan bukan kepada laki-laki budak. Imam Shafi’i berargumentasi

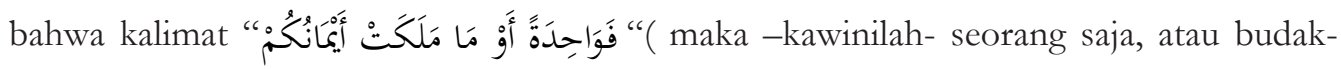
budak yang kamu miliki). Orang yang memiliki budak hanyalah laki-laki merdeka, sementara laki-laki budak pasti tidak memilikinya. Pemahaman ini juga didukung kalimat berikutnya

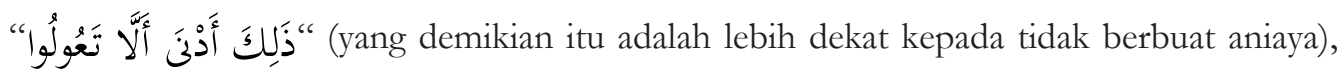


ljtihad, Jurnal Wacana Hukum Islam dan Kemanusiaan, Volume 17, No. 1, Juni 2017:61-84

yang berbuat aniaya adalah orang yang memiliki harta. Sedangkan budak tidak memiliki harta (Shafi'i, 1990 : 44). Ayat lain yang terkait dengan poligami terdapat dalam al-Qur'an surat al-Nisa' (4) ayat 129:

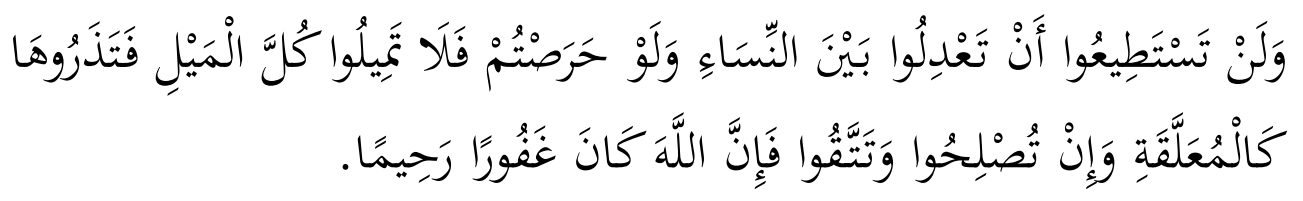

Ukuran adil yang dipakai sebagai syarat adalah adil yang dapat dilihat dan ditimbang, tentunya yang bersifat lahiriyah dan kuantitatif, seperti pakaian, tempat tinggal, uang belanja, hari kebersamaan (hari gilir) dan segala sesuatu yang bisa diukur dengan mata. Sedang yang bersifat kualitatif atau rasa hanya Allah yang tahu, bahkan sang suami sebagai pelaku poligamipun tidak bisa mengukur dari segi kualitasnya. Keadilan secara kualitatif ini tidak mungkin dapat diukur dan dipenuhi oleh manusia sekalipun sang pelaku berniat untuk melakukan itu. Secara pribadi Rasulullah sendiri melarang Ali bin Abi Thalib, sang menantu untuk mempoligami siti Fatimah, sebagaimana hadith di bawah ini :

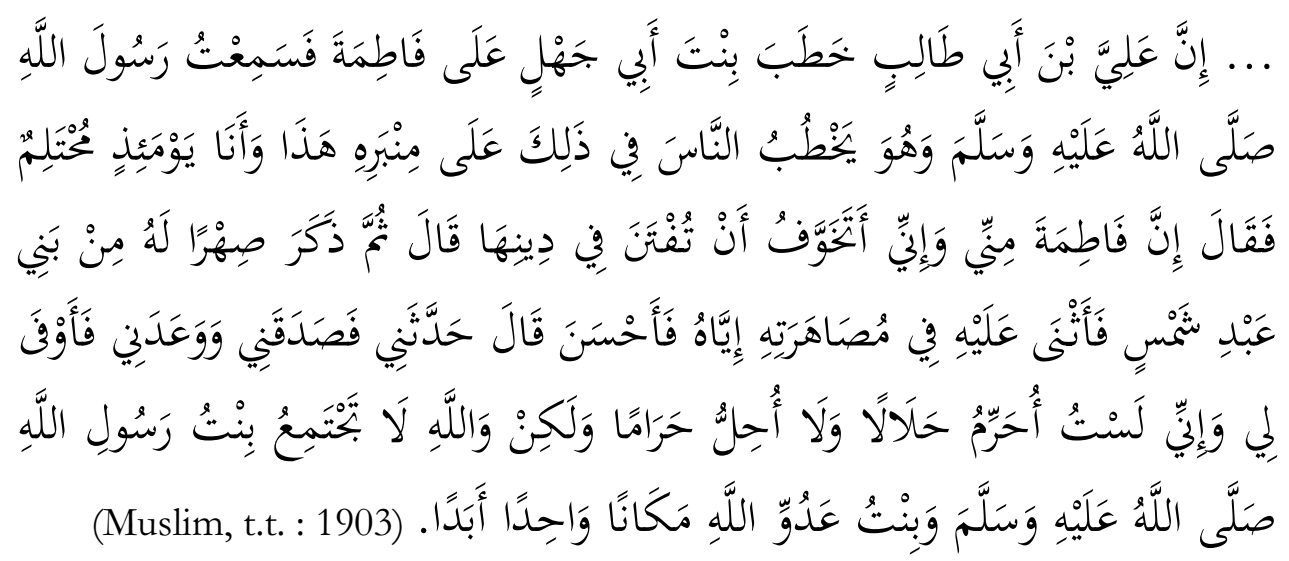

Hal ini memberi pemahaman betapa beratnya pelaksanaan poligami, sehingga belum tentu setiap orang bisa menjalankannya dengan adil sesuai dengan apa yang difirmankan Allah dalam al Qur'an dan disabdakan rasul dalam hadis-hadisnya, bukan bermakna pengharaman Poligami . 


\section{Analisis fikih Mazhab Shafi'i terhadap konsep CEDAW tentang poligami}

Berdasarkan pada uraian di atas dapat dianalisa bahwa Rumusan CEDAW yang kemudian diadopsi negara-negara dalam membuat rumusan hukum Islam model baru yang disusun berdasarkan prinsip-prinsip dasar ajaran Islam sebagaimana dalam al-Qur'an dan Sunnah Nabi yang sangat menghormati hak asasi manusia, mengadvokasi kesetaraan dan keadilan gender, menyuarakan pandangan yang humanis, pluralis dan demokratis. Ajaran Islam yang dasar bersumber dari al-Qur'an dan Hadis bersifat mutlak, kekal, absolut dan yang tdk bisa diubah. Yang termasuk non dasar adalah Fiqh sebagai upaya penggalian al-Qur'an dan Hadis hasil olah pikir manusia yang cerdas, yang sangat dimungkinkan terdapat kesalahan, kekurangan ataupun tidak lagi sesuai dengan masanya, karena dipengaruhi faktor sosio kultural dan historis masyarakat pada masa hidup sang mujtahid, sehingga tidak mungkin hasil ijtihad itu berlaku abadi sepanjang masa, tetapi dalam kurun waktu tertentu masih memungkinkan untuk berubah.

Imam Shafi'i melandasi pemikirannya berdasar ilahiyah yang sudah diatur dalam al-Qur'an dan Sunnah. Pertimbangan agama dan nilai baik dan buruk serta mempercayai adanya kehidupan akhirat (surga dan neraka) dan dunia sebagai sarana akhirat. Sedangkan jika berdasarkan pada pertimbangan pikiran atau kemauan atau kenyataan yang terjadi maka akan terjadi penafsiran-penafsiran yang mengikuti pada keinginan manusia. Keinginan, pikiran dan bukti nyata tidaklah sama.

Konsep adil yang dipergunakan CEDAW dengan pertimbangan hak asasi manusia yang merupakan kesepakatan manusia yang didasarkan pada pertimbangan keadilan dalam ranah pertimbangan akal manusia yang bersifat duniawi (apa yang dilihat dan apa yang dirasa saja). Bagaimana manusia memiliki rasa keadilan pada seluruh kehidupannya seperti politik, semua mempunyai hak yang sama untuk bersuara, berpendapat menjadi pemimpin dan lain sebagainya. Sedangkan adil dalam Mazhab Shafi'i bersifat gelobal dan diakui untuk kehidupan yang selamanya yang didasarkan pada kecintaan dan menyatunya dengan Allah Yang Maha kekal. Lembaga pernikahan adalah hanya ibadah hanya karena Allah semata yang didasarkan pada bagaimana menjadi hamba Allah yang saleh/salihin.

Mazhab Shafi'i memahami ayat al-Qur'an sebagai sumber hukum utama dan pertama serta menggunakan akal dalam penetapan hukum sebatas pada penggunaan Qiyas, itupun 
ljtihad, Jurnal Wacana Hukum Islam dan Kemanusiaan, Volume 17, No. 1, Juni 2017: 61-84

jika ada kaitannya dengan wahyu, karena semua permasalahan yang dihadapi sudah tersedia jawabannya dalam al-Qur'an. Sehingga jika sudah diatur dan dijelaskan dalam nash, maka penggunaan sumber lain yaitu akal tidak diperbolehkan lagi. Sedangkan sumber konsep yang dijadikan sebagai paradigma CEDAW adalah akal pikiran, nafsu kemauan dan perasaan sehingga konsep CEDAW dinilai cukup rasional dan mașlạ̣ah. Konsep madarat dan maṣlaḥah dalam CEDAW berpijak pada akal pikiran, nafsu kemauan dan perasaan. Sumber konsep paradigma Mazhab Shafi'i adalah akal pikiran dan hati yang didasarkan pada teks agama. Jika agama melarang, pasti ada madarat untuk manusia, di dunia dan di akhirat. Jika di dunia belum tampak Madarat-nya, pasti di akhirat akan dirasakan. Prinsip mașlạ̣ah yang terkandung di dalam pemikiran CEDAW, dalam Mazhab Shafi'i masuk kategori al-mașlạ̣ah al-Mulgāh, karena prinsipnya bertentangan dengan ajaran hukum Islam yang terdapat dalam teks agama. Pola kemaslahatan jenis ini bukan hanya ditentang oleh mazhab Shafi'i, tetapi seluruh ulama Islam menentangnya.

Dalam penetapan hukum Poligami, CEDAW (kaum Feminis) menggunakan Daläah Nash yang memahami petunjuk ayat dengan mempertimbangkan Siyāq al- Kaläm. Sehingga memaknai adil lebih bersifat pada rasa (kualitatif) yaitu dalam cinta dan kasih sayang. Poligami akan semakin menjauhkan dari mu'asharah bi al-ma'rüf karena menyebabkan penderitaan istri. Dengan pertimbangan sadd al dhariah, para pakar feminis merubah hukum mubah Poligami menjadi ḥaram li ghairihi. Sada al dhari'ah adalah upaya mujtahid untuk menetapkan larangan terhadap satu kasus hukum yang pada dasarnya berhukum Mubah (Hamidah, 2011: 126). Larangan tersebut dimaksudkan untuk menghindari perbuatan lain yang dilarang. Dengan kata lain tindakan ini adalah sebagai langkah preventif agar segala sesuatu yang diperbolehkan tetapi membawa dampak yang buruk yang bisa mengarah pada keharaman, maka dihukumi haram.

Mazhab Shafi'i menggunakan dalālah 'ibārah yang memahami petunjuk ayat tanpa mempertimbangkan Siyāq al-Kaläm. Pemilihan metode ini jelas akan mempunyai kecenderungan masing-masing dalam memahami petunjuk ayat. Contohnya dalam masalah pemaknaan adil dalam ayat poligami, maka para fuqaha' klasik memaknai adil dalam materi dan pembagian waktu kebersamaan (gilir) yang bersifat kuantitatif. Hukum harām li gairihi atas kebolehan Poligami dengan berdasarkan Sadd al-dhari'ah adalah tidak bisa diberlakukan 
secara umum. Sebagaimana syari'at nikah yang pada hukum asalnya mubah, bisa berubah menjadi haram jika sang pelaku tidak mampu untuk menikah, tidak ingin menikah, dan tidak punya hasrat seksual terhadap lawan jenis. Jika dia menikah pasti akan membawa kerusakan bagi sang istri. Kemubahan poligami ini tidak bisa ditarik secara tegas menuju pada harām li ghairihi, tetapi melihat pada kondisi tertentu dengan pertimbangan kondisi si pelaku.

Untuk memetakan uraian-uraian di atas, paradigma pemikiran CEDAW dalam analisa paradigma pemikiran mazhab Shafi'i dapat dirumuskan sebagai berikut:

Tabel 3

Paradigma pemikiran CEDAW dan mazhab Shafi'i

\begin{tabular}{|c|c|c|c|}
\hline \multirow[t]{2}{*}{ No } & \multirow[t]{2}{*}{ Permasalahan } & \multicolumn{2}{|c|}{ Paradigma pemikiran } \\
\hline & & CEDAW & Mazhab Shafi'i \\
\hline 1. & Sumber konsep & $\begin{array}{l}\text { Bukti kenyataan, akal pikiran, } \\
\text { kemauan dan perasaan }\end{array}$ & $\begin{array}{l}\text { teks agama yang dipahami } \\
\text { dengan akal pikiran dan hati }\end{array}$ \\
\hline 2. & Kemaslahatan & $\begin{array}{l}\text { Didasarkan pada akal pikiran } \\
\text { dan perasaan }\end{array}$ & $\begin{array}{l}\text { teks agama: semua hukum } \\
\text { Allah pasti maslahat } \\
\text { sekalipun menurut akal } \\
\text { pikiran dan perasaan ada } \\
\text { madharat }\end{array}$ \\
\hline 3. & Prinsip keadilan & $\begin{array}{l}\text { Keadilan duniawi (harta, tahta } \\
\text { dan asmara) }\end{array}$ & $\begin{array}{l}\text { Keadilan menurut Allah, } \\
\text { semua hukum Allah pasti adil }\end{array}$ \\
\hline 4. & $\begin{array}{l}\text { Kedudukan wali } \\
\text { nikah }\end{array}$ & $\begin{array}{l}\text { Persamaan gender menghapus } \\
\text { diskriminasi: wanita boleh jadi } \\
\text { wali }\end{array}$ & $\begin{array}{l}\text { Teks agama: Perwalian wajib } \\
\text { berada di tangan laki-laki; } \\
\text { wanita tidak boleh }\end{array}$ \\
\hline 5. & $\begin{array}{l}\text { Wali nikah bagi } \\
\text { gadis }\end{array}$ & $\begin{array}{l}\text { Persamaan gender menghapus } \\
\text { diskriminasi: wanita boleh } \\
\text { menikah tanpa wali } \\
\text { sebagaimana laki-laki }\end{array}$ & $\begin{array}{l}\text { Teks agama: wanita harus ada } \\
\text { wali, kecuali janda. }\end{array}$ \\
\hline 6. & Saksi pernikahan & $\begin{array}{l}\text { Persamaan gender menghapus } \\
\text { diskriminasi: wanita boleh } \\
\text { seperti laki-laki }\end{array}$ & $\begin{array}{l}\text { Teks agama: wanita tidak } \\
\text { boleh jadi saksi }\end{array}$ \\
\hline 7. & Mahar & $\begin{array}{l}\text { Persamaan gender menghapus } \\
\text { diskriminasi: wanita boleh } \\
\text { memberi mahar sebagaimana } \\
\text { laki-laki }\end{array}$ & $\begin{array}{l}\text { Teks agama: pemberi mahar } \\
\text { adalah suami }\end{array}$ \\
\hline
\end{tabular}


ljtihad, Jurnal Wacana Hukum Islam dan Kemanusiaan, Volume 17, No. 1, Juni 2017:61-84

\begin{tabular}{|c|c|c|c|}
\hline \multirow[t]{2}{*}{ No } & \multirow[t]{2}{*}{ Permasalahan } & \multicolumn{2}{|c|}{ Paradigma pemikiran } \\
\hline & & CEDAW & Mazhab Shafi'i \\
\hline 8. & $\begin{array}{l}\text { Kedudukan } \\
\text { suami istri }\end{array}$ & $\begin{array}{l}\text { Persamaan gender menghapus } \\
\text { diskriminasi: suami istri } \\
\text { memiliki kedudukan, hak dan } \\
\text { kewajiban yang sama }\end{array}$ & $\begin{array}{l}\text { Teks agama: laki-laki wajib } \\
\text { memberi nafkah, kepala } \\
\text { keluarga. }\end{array}$ \\
\hline 9. & Poligami & $\begin{array}{l}\text { Persamaan gender menghapus } \\
\text { diskriminasi: pria tidak } \\
\text { diperbolehkan, sebagaimana } \\
\text { wanita tidak diperbolehkan }\end{array}$ & $\begin{array}{l}\text { Teks agama: laki-laki boleh } \\
\text { poligami maksimal empat }\end{array}$ \\
\hline 10. & Iddah & $\begin{array}{l}\text { Persamaan gender menghapus } \\
\text { diskriminasi: berlaku bagi } \\
\text { suami istri, jika disyaratkan }\end{array}$ & Teks agama: hanya untuk istr \\
\hline 11. & Seks & $\begin{array}{l}\text { Kepuasan seksual, dan } \\
\text { memperoleh keturunan. }\end{array}$ & $\begin{array}{l}\text { Teks agama: seks dalam } \\
\text { pernikahan adalah ibadah, } \\
\text { untuk mengagungkan Allah }\end{array}$ \\
\hline 12. & Zina & $\begin{array}{l}\text { Boleh, sepanjang tidak } \\
\text { merugikan kedua belah pihak } \\
\text { (syaratnya tidak melanggar } \\
\text { HAM) }\end{array}$ & $\begin{array}{l}\text { Teks agama: perbuatan } \\
\text { terlarang (haram), masuk } \\
\text { neraka, tidak mengagungkan } \\
\text { Allah }\end{array}$ \\
\hline
\end{tabular}

Pernikahan didasarkan pada hanya semata-mata ibadah karena Allah, maka apapun yang terjadi adalah dilandasi pada mencapai Ridha dan keagungan-Nya. Jika kebolehan poligami dalam hukum perkawinan di Indonesia dan kompilasi hukum Islam dikarenakan salah sang istri tidak bisa melayani sang suami atau sakit atau tidak memperoleh keturunan, maka berarti itu adalah hukum yang jauh dari tuntunannya Allah. Karena kalau hanya berdasarkan pertimbangan keturunan, maka pasti Allah akan memperbolehkan Poliandri. Analisa tentang konsep dasar pertimbangan manusia tentang hukum Islam dapat dirumuskan sebagai berikut: 


\section{Tabel 4}

\section{Konsep dasar pertimbangan manusia}

\begin{tabular}{|c|c|c|c|c|}
\hline \multirow[t]{2}{*}{ No } & & \multicolumn{3}{|c|}{ Dasar pertimbangan } \\
\hline & & Nafsu & Akal & Hati \\
\hline \multirow[t]{2}{*}{1.} & $\begin{array}{l}\text { Sumber } \\
\text { konsep }\end{array}$ & $\begin{array}{l}\text { Pikiran, kemauan, } \\
\text { perasaan }\end{array}$ & Bukti/kenyataan & Keagungan Allah \\
\hline & & $\begin{array}{l}\text { Keadilan duniawi } \\
\text { (tahta, harta dan }\end{array}$ & $\begin{array}{l}\text { Dunia sebagai } \\
\text { sarana akhirat }\end{array}$ & Keagungan Allah \\
\hline \multirow[t]{2}{*}{2.} & $\begin{array}{l}\text { Konsep } \\
\text { keadilan }\end{array}$ & $\begin{array}{l}\text { asmara) } \\
\text { a. Politik } \\
\text { b. Ekonomi } \\
\text { c. Nikah }\end{array}$ & $\begin{array}{l}\text { (iman, ibadah, } \\
\text { akhlak) }\end{array}$ & \\
\hline & & $\begin{array}{l}\text { Keadilan } \\
\text { perorangan/ parsial } \\
\text { dan sesaat }\end{array}$ & $\begin{array}{l}\text { Keadilan global dan } \\
\text { selamanya }\end{array}$ & $\begin{array}{l}\text { Kecintaan dan } \\
\text { menyatunya dengan } \\
\text { Allah yang maha } \\
\text { kekal }\end{array}$ \\
\hline \multirow[t]{2}{*}{3.} & Pernikahan & Kepuasan seksual & $\begin{array}{l}\text { Dengan pernikahan } \\
\text { untuk memperoleh } \\
\text { keturunan dan } \\
\text { penyaluran nafsu }\end{array}$ & $\begin{array}{l}\text { Dengan pernikahan } \\
\text { yaitu ibadah karena } \\
\text { Allah }\end{array}$ \\
\hline & & $\begin{array}{l}\text { Hak asasi sebagai } \\
\text { pertimbangan. }\end{array}$ & $\begin{array}{l}\text { Merugikan orang } \\
\text { lain, melanggar }\end{array}$ & $\begin{array}{l}\text { Zina tidak } \\
\text { mengagungkan Allah }\end{array}$ \\
\hline \multirow[t]{2}{*}{4.} & $\begin{array}{l}\text { Tentang } \\
\text { zina }\end{array}$ & $\begin{array}{l}\text { Pelarangan } \\
\text { pemenuhan nafsu seks } \\
\text { berarti pelanggaran } \\
\text { HAM }\end{array}$ & $\begin{array}{l}\text { HAM, di akhirat } \\
\text { masuk neraka }\end{array}$ & \\
\hline & Kedudukan & $\begin{array}{l}\text { Hewani (manusia } \\
\text { sebagai hewan yang } \\
\text { tidak diberi akal) }\end{array}$ & $\begin{array}{l}\text { Manusia sebagai } \\
\text { pemilik akal }\end{array}$ & $\begin{array}{l}\text { Manusia sebagai } \\
\text { hamba Allah }\end{array}$ \\
\hline \multirow{2}{*}{5.} & manusia & dan ditolong syetan & Ditolong malaikat & Ditolong Allah \\
\hline & $\begin{array}{l}\text { Tahap } \\
\text { akhir }\end{array}$ & $\begin{array}{l}\text { Yang dimurkai dan } \\
\text { yang sesat }\end{array}$ & $\begin{array}{l}\text { Tidak ada yang } \\
\text { disembah kecuali } \\
\text { Allah }\end{array}$ & $\begin{array}{l}\text { Tidak ada yang wujud } \\
\text { kecuali Allah }\end{array}$ \\
\hline \multirow{2}{*}{6.} & hidup & & Orang saleh & Mengetahui \\
\hline & manusia & & Para syuhada & Benar \\
\hline
\end{tabular}

Allah menciptakan manusia dilengkapi dengan nafsu, akal dan hati yang ketiganya dapat dijadikan sebagai pertimbangan bagi manusia dalam menghadapi atau menyelasaikan suatu masalah. Pertimbangan nafsu hanya didasarkan pada pikiran, kemauan dan perasaan, rasa 
ljtihad, Jurnal Wacana Hukum Islam dan Kemanusiaan, Volume 17, No. 1, Juni 2017: 61-84

enak atau tidak enak, suka atau tidak suka. Nafsu ini mengesampingkan akibat yang mungkin ditimbulkan dari perbuatannya. Nafsu ini didasarkan pada sifat dasar manusia yang keinginannya selalu ingin terlaksana. Konsep keadilan menurut pertimbangan nafsu ini adalah keadilan duniawi saja, yaitu untuk pemenuhan kebutuhan yang berhubungan dengan tahta (jabatan, kekuasaan), harta dan asmara (termasuk di dalamnya adalah pemenuhan kebutuhan seks/libido).

\section{Penutup}

Mazhab Shafi'i berpendapat bahwa Poligami hukum dasarnya boleh sebagaimana dijelaskan dalam al-Qur'an dan hukum tersebut bisa berubah sesuai dengan kondisi yang menyertainya. CEDAW adalah suatu konvensi PBB tentang penghapusan segala macam bentuk diskriminasi terhadap perempuan. Segala hukum yang mengandung unsur diskriminasi termasuk dalam hukum perkawinan berarti melanggar HAM dan CEDAW. Pasal 16 CEDAW menyatakan perempuan dan laki-laki mempuyai hak yang sama termasuk dalam hal kebolehan poligami bagi laki-laki merupakan perlakuan diskriminatif di hadapan hukum yang harus dihapus karena bertentangan dengan HAM dan CEDAW. Menurut Mazhab Shafi'i hukum poligami bisa berubah sesuai dengan kondisi pelaku adalah merupakan solusi atas permasalahan yang ada. Pertimbangan kemaslahatan, maqāsid al-shari'ah, akal publik, kearifan lokal yang ditawarkan CEDAW yang menghukumi poligami haram li-ghairihi adalah bertentangan dengan teori kemaslahatan dan maqāsid al-shari'ah yang tidak hanya berdasar pertimbangan kebahagiaan dunia tetapi kebahagiaan di alam akhirat yang selama-lamanya

\section{Daftar pustaka}

Abdullah, Sulaiman. Konsep al-Qiyas Imam al-Shafi'iy dalam Perspektif Pembaharuan Hukum Islam. Disertasi. Jakarta: IAIN Syarif Hidayatulloh,1993.

Abu Syuqqah, Abdul Halim Muhammad. Taḥrir al-Mar'ah fi 'Așr al-Risālah. Terj. Mujiyo. Bandung: Al Bayan, 1993.

Abu Zayd, Nasr Hamid. Imam Syafii Moderatisme, Eklektisisme, Arabisme. Yogyakarta: LkiS. 1997.

Azizy, A. Qodri. Reformasi Bermadz̧hab Sebuah Ikhtiar Menuju Ijtihad Sesuai Saintifik-Modern. Jakarta: Teraju, 2003.

Baidowi, Ahmad. Tafsir Feminis, Kajian Perempuan dalam al-Qur'an dan Para Mufassir Kontemporer. Bandung: Nuansa. 1985. 
Bisri, Cik Hasan. Pilar-pilar Penelitian Hukum Islam dan Pranata Sosial. Jakarta: Raja Grafindo Pratama, 2004.

Batara Murti, Ratna, dkk. Respon Islam atas Pembakuan Perempuan. Jakarta: LBH APIK, 2005. Billah. Religion And Human Rights. Terj. Ahmad Suaedy dan Elga Sarapung. Ed. John Kelsay dan Sumner B. Twiss. Jakarta: Institut Dian, 1994.

Departemen Agama RI. Al-Qur'an dan Terjemahnya. Semarang: PT. Karya Toha Putra, 1995. Dharma, Surya. Konsep dan Teknik Penelitian Gender Malang: Penerbitan Univesitas Muhammadiyah Malang, 2002.

Dzuhayatin, Siti Ruhaini dkk. Rekonstruksi Metodologis Wacana Kesetaraan Gender Dalam Islam. Yogyakarta: PSW IAIN Sunan Kalijaga, 2002.

Farran, Syaikh Ahmad Musthafa Al. Tafsir al Imam Asy-Syafi'i. Terj Ali Sultan dan Fedrian Hasmand. Jakarta: Almahira, 2008.

Ferricha, Dian. Sosiologi Hukum dan Gender: Interaksi Perempuan dalam Dinamika Norma dan Sosio-Ekonomi. Malang: Bayumedia, 2010.

Ghozali, Abdul Rahman. Fiqh Munakahat. Jakarta: Kencana Prenada Media Group, 2003.

Ghozali, Abdul Moqsit dkk. Tubuh, Seksualitas dan Kedaulatan Perempuan. Bunga Rampai Pemikiran Ulama Muda. Yogyakarta: LKiS. 2002.

Hamidah, Tutik. Fiqh Perempuan Berwawasan Keadilan Gender. Malang: UIN-Maliki Press, 2011. Hasyim, Syafiq. Hal-hal yang Tak Terpikirkan Tentang Isu-isu Keperempuanan Dalam Islam. Bandung: Mizan, 2001.

Ilyas, Yunahar. Feminisme Dalam Kajian Tafsir Al-Qur'an Klasik dan Kontemporer. Yogyakarta: Pustaka Pelajar, 1997.

Ishomuddin. Sosiologi Prespektif Islam. Malang: UMM Press, 2005.

Jurnal Perempuan No. 45 Januari. Jakarta: Yayasan Jurnal Perempuan, 2006.

Katjasungkana, Nursyahbani Ed. Pengahapusan Diskriminasi Terhadap Kaum Perempuan. Jakarta: AAPIK, tt.

Lapian, L.M. Gandhi. Disiplin Hukum Yang Mewujudkan Kesetaraan dan Keadilan Gender. Jakarta: Yayasan Pustaka Obor Indonesia, 2012.

Mansour, Fakih. Analisis Gender dan Transformasi Sosial. Bandung: Pustaka Pelajar, 1996.

Megawangi, Ratna. Membiarkan Berbeda? Sudut Pandang Baru Tentang Relasi Gender. Bandung: PT. Mizan, 1999.

Mernisi, Fatimah dan Riffat Hassan. Setara Dihadapan Allah. Yogyakarta: LSPPA, 2001.

Mubarok, Jaih. Sejarah Dan Perkembangan Hukum Islam. Bandung: PT. Remaja Rosdakarya, 2000.

Mustaqim, H. Abdul. Paradigma Tafsir Feminis, Membaca al Qur'an dengan Optik Perempuan, 
ljtihad, Jurnal Wacana Hukum Islam dan Kemanusiaan, Volume 17, No. 1, Juni 2017: 61-84

Studi Pemikiran Riffat Hasan Tentang Isu Gender dalam Islam. Yogyakarta: Logung Pustaka. 2008.

Muthahhari, Murtadha. The Right of Women in Islam. Terj. M. Hashem. Bandung: PT. Lentera Basritama, 2000.

Mufidah. Bingkai Sosial Gender, Islam, Strukturasi dan Konstruksi Sosial. Malang: UIN-Maliki Press, 2010.

Mulia, Siti Musdah. Islam menggugat Poligami. Jakarta: Gramedia. 2006.

Nugroho, Riant. Gender dan Strategi Pengarusutamaannya di Indonesia. Yogyakarta: Pustaka Pelajar. 2008.

Nuruzzaman, dkk. ed. Islam Agama Ramah Perempuan, pembelaan kiai Pesantren. Yogyakarta: LkiS, 2007.

Rahmaniyah, Inayah dan Moh. Sidik Ed. Menyoal Keadilan dan Poligami. Yogyakarta: PSW UIN Sunan Kalijaga. 2009.

Rofiq, Ahmad. Pembaharuan Hukum Islam di Indonesia. Yogyakarta: Gama Media, 2001.

Roibin. Sosiologi Hukum Islam, Telaah Sosio Histori Pemikiran Imam Syafi’i. Malang: UIN-Malang Press, 2008.

Said, Nur. Perempuan dalam Himpitan Teologi dan HAM di Indonesia. Yogyakarta: PT. Pilar Religia, 2005.

San'any, Muhammad Ibnu Ismail Al-. Subul al-Saläm. Vol. 3 Beirut: Dar al-Fiker, 1993.

Saleh, Abdul Mun'im. Maz̧hab Syafii Kajian Konsep al-maslạ̣ah. Yogyakarta: Ittaqa Press, 2001.

Salikin, Adang Djumhur. Reformasi Syariah dan HAM dalam Islam, Bacaan Kritis terhadap Pemikiran An-Naim. Yogyakarta: Gama Media, 2004.

Shafi'i, Muhammad bin Idris Al. Al-Umm. Vol. 5, Bairut: Dar al-Fikr, 1990.

Shabuni, Muhammad Ali Al. Șofwat al-Tafäsir. Vol. I, Beirut: Dar al-Qur'an al- Karim, 1980.

Sukri, Sri Suhanjati. Bias Jender dalam Pemahaman Islam. Yogyakarta: Gama Media, 2002.

Shihab, M. Quraisy. Wawasan Al-Qur'an, Tafsir Tematik. Atas Pelbagai Persoalan Umat. Bandung: PT. Mizan Pustaka, 2007.

Subhan, Zaitunah. Kekerasan terhadap Perempuan. Yogyakarta: Pustaka Pesantren, 2004.

Turmudhi, Imam. Sunan al-Tirmidhi. Bairut: Dar al-Fikr li al-Taba'ah wa al-Nashr, t.t.

Umar, Nasaruddin. Argumen Kesetaraan Gender Perspektif al-Qur'an. Jakarta: Paramadina, 2001.

Yahya, Mukhtar. Dasar-Dasar Pembinaan Hukum Figh Islam. Bandung: PT. al Ma'arif, 1993.

Zuhdi, Zaenu. Ibadah Penganut Tarekat; Studi tentang Mazhab Fikih Tarekat Qadiriyah wa Naqshabandiyah, Shiddiqiyyah dan Shadhiliyah di Jombang. Disertasi. Surabaya: IAIN Sunan Ampel, 2013. 